\title{
Human parvovirus B19 IgM antibodies among blood donor in Basra
}

\section{Wijdan Nazar Ibraheim. Department of Microbiology, College of Medicine, University of Basrah.}

\begin{abstract}
One of the main methods for B 19 Parvovirus transmission is by blood and its products. Screening test for this virus is not yet applicable; in spite of its association with some sever complication. So that the aim of this study was to estimate the level of HPVB19 $\operatorname{IgM}$ antibodies among blood donor in centre of
\end{abstract}

Basra.

A total of 189 blood samples were drawn from healthy blood donor attending the blood bank in Basrah governorate from the period of January -May 2016. Detection of parvovirus B19 IgM antibodies was done using a solid phase enzyme-linked immunosorbent assay.

In this study the researcher found that highest seropositivity were found among age 30-39 years $(62.6 \%)$ and the lowest group level among those above 40 years $(0 \%)$, with

\begin{abstract}
:
overall prevalence of $\operatorname{IgM} 51.1 \%$ this high percentage may related to the time of sampling which coincide with the maximum period of infectivity which was more common in late winter, spring, and early summer.

Regarding the association between $\mathrm{ABO}$ blood groups and susceptibility to infection: the rate of infection more among those with blood group $\mathrm{O}+$ and $\mathrm{B}+(54.9 \%)$ and $(27.5 \%)$ respectively this is depend on the availability of blood antigen $\mathrm{P}$ which act as receptors for this virus, and highest level of HPV IgM was found among the taxi drivers so in conclusion: Screening for B19 virus antibodies is recommended together with other viruses which transmitted by blood transfusion to avoid transmission of this important virus to vulnerable risky group.
\end{abstract}

Key words: blood, donor, B19 virus, IgM 


\section{Introduction:}

Human blood and its components are widely used as life saving therapy in hospital practices. However, there is always an associated risk of transfusion reactions due to viral transmission via contaminated blood.

\section{Parvovirus B19 (PVB19) is a DNA virus}

belonging to the parvoviridae family and erythrovirus genus (Satish Kumar et al., 2013). It is one of the transfusion transmissible viruses. As well as others including human immunodeficiency virus (HIV), hepatitis B virus (HBV), hepatitis $\mathrm{C}$ virus (HCV), cytomegalovirus (CMV), human $\mathrm{T}$ cell leukaemia virus I (HTLV1), and Epstein-Barr virus (EBV) (H. L. Zaaijer et al., 2004).

HPV have 3 genotypes 1, 2 and 3.

Genotype 1 is responsible for the majority of human infections worldwide; genotypes 2 and 3 appear to have some geographic and temporal variation in distribution. The virus is resistant to dry heat, freezing and lipid solvents. It is became inactivated by the effect of gamma irradiation, $\beta$-propiolactone and formalin

(Bärbel Kaufmann et al., 2004).

The virus is transmitted primarily by droplet, and can be transmitted vertically through placental to the fetus and through blood transfusion especially at risk population including children, immunocompromised, pregnant women, and those with chronic haemolytic anemia such as thalassemia and sickle cell patients (Young NS et al., 2004).
It has been noticed that this virus cannot

be eliminated from patients with immunodeficiency disorder like: AIDS (acquired immune deficiency syndrome), leukemic children, organ transplantation and any other patient receiving chemotherapy, this problem may cause chronic anemia in these victims and they consider as highly contagious during aplastic crisis (Musa et al., 2013). However intra-muscular injection of parvo B19 antibodies will effectively eradicate the infection in immuno-compromised individuals (Yoto, Y. et al., 2008, Musa et al., 2013).

Similar findings of anti-parvovirus $\operatorname{IgG}$ antibody seroprevalence rates were reported in the United States, Europe, and Asia ((Bärbel Kaufmann et al., 2004, Young NS et al., 2004, Manaresi E et al., 2004).

The virus has a direct cytopathic effect on erythroid progenitors in bone marrow leading to invasion and destruction of red blood cell precursors and arrest in the maturation and subsequent anaemia (Chisaka $\mathrm{H}$ etal., 2003).The clinical symptom varies widely depending on the haematological status and immunological background of the individual.

So If such viral infection take place in individuals with any type of haemolytic disorders, such as sickle cell anaemia (SCA), thallasemia ,spherocytosis that will lead to merging of two anemia-induced mechanisms: hemolysis and dropped off red cell production ( Blaeser F et al.,2005), the result is temporary 
fall in haemoglobin level with aplastic crisis" or "marrow failure( an abnormal decrease of reticulocytes in the body which may require additional blood transfusion this known as (TEB) transient erythroblastopenia (Wei O et al.,2006, Smith-Whitley K et al., 2004)').

While a minor or insignificant fall in haemoglobin level about 1g/dl could occur in healthy child as a result of such infection, due to temporary failure in the synthesis of red cell until the immune system eradicates the virus from the body, usually within 10 days ${ }^{2}(\mathrm{H}$. L.

Zaaijer et al., 2004).

In this situation, the short cessation of

RBCS production and supply caused by parvoB19 infection will enhance an"aplastic crisis"like severe anaemia(Smith-Whitley $\mathrm{K}$ et al., 2004) .So these patients suffering from lethargy, sever pallor and sometimes come with cardiac failure, and require blood transfusion. Vaccine for HPB19 is available and will benefit this high risk group (Ke L et al., 2011).

Several studies have been reported the presence of a persistent B19 low level viraemia beyond 6 months' post-infection with a degree of immunodeficiency, (Blaeser F et al.,2005). Recent data using highly sensitive molecular technology suggest that viral DNA may persist in the circulation of healthy normal individuals

(Cassinotti P et al., 2000).

Yoto, Y. et al., (2008) had recommended applying of a screening test for each blood donor to discover HPV B19 DNA in order to avoid viral infection mediated by blood transfusion or blood products especially for those with high risk groups (Yoto, Y. et al., 2008). However, HPV19 screening of blood and blood products for transfusion is not done routinely in Basra. Therefore, this study was aimed to estimate the level of HPVB $19 \operatorname{IgM}$ antibodies among the blood donor at the blood donor centre in Basrah city, south of Iraq.

\section{Materials and methods:}

During the period from January to May 2016 a total of 189 blood donations at the Institute of Blood bank in the center of Basra governorate were screened for HPV B19 IgM. Predominant population in this study was male.

After taken a full permission and agreement from the involved participants, 4 $\mathrm{mL}$ of venous blood was collected by venipunctur using a sterile disposable needle and a vacuum tube from each study participant, by a medical practitioner's staff. The blood samples were transferred to the laboratory at the college of medicine university of Basra for further processing.

After clotting, blood samples in the plain tubes were centrifuged at 3,000 rpm for 10 minutes and the resulting sera were collected into separate cryo tubes for serological analysis of parvovirus B19 infection. The serum was used immediately or stored at $-20^{\circ} \mathrm{C}$ prior to use. 
Detection of parvovirus B19 IgM

antibodies was done using a solid phase enzyme-linked immunosorbent assay (ELISA) (from Parvovirus B19 IgM ELISA -DRG, international, Inc, Germany). The DRG Parvovirus B19 IgM ELISA Kit is a solid phase enzyme-linked immunosorbent assay (ELISA). The procedure was performed according to manufacturer's instructions.

\section{Statistical analysis:}

Statistical Package for Social Science (SPSS) version17 was used to analyze the data. Chi-square $\left(\mathrm{X}^{2}\right)$ was used to assess the Table 1- The general characteristics of the Study population

\begin{tabular}{|c|c|c|}
\hline Age groups & Percent $\%$ & Frequency \\
\hline $20-$ & $38.6 \%$ & 73 \\
\hline $30-$ & $46.1 \%$ & 87 \\
\hline $40-$ & $15.3 \%$ & 29 \\
\hline Blood groups & & \\
\hline $\mathrm{AB}+$ & $13.2 \%$ & 25 \\
\hline $\mathrm{A}-$ & $3.7 \%$ & 7 \\
\hline B+ & $25.4 \%$ & 48 \\
\hline O+ & $38.6 \%$ & 73 \\
\hline $\mathrm{A}+$ & $15.3 \%$ & 29 \\
\hline O- & $3.7 \%$ & 7 \\
\hline Occupation & & \\
\hline Taxi driver & $22.8 \%$ & 43 \\
\hline Free worker & $38.6 \%$ & 73 \\
\hline Employer & $33.9 \%$ & 64 \\
\hline student & $4.8 \%$ & 9 \\
\hline Total & & 189 \\
\hline \multicolumn{2}{|r}{} \\
\hline
\end{tabular}

The distribution of HPVB19 IgM Abs was shown in table 2, which show that the highest seropositivity was found among age group 30-40 years $62.6 \%$ and the lowest level among those above $40 y e a r s$ and the difference was statistically significant $<0.05$. 
Table2- the distribution of HPVB19 IgM Abs according to the age groups.

\begin{tabular}{|c|c|c|c|}
\hline \multirow{2}{*}{ Age Groups } & \multicolumn{2}{|c|}{ HPVB19 IgM } & \multirow{2}{*}{ Total } \\
\cline { 2 - 3 } & $\begin{array}{c}\text { Negative } \\
\text { No. } \%\end{array}$ & $\begin{array}{c}\text { Positive } \\
\text { No. \% }\end{array}$ & \\
\hline $20-\quad$ years & 39 & 34 & 73 \\
& $39.8 \%$ & $37.4 \%$ & $38.6 \%$ \\
\hline $30-$ & 30 & 57 & 87 \\
& $30.6 \%$ & $62.6 \%$ & $46 \%$ \\
\hline $40-$ & 29 & 0 & 29 \\
& $29.6 \%$ & $0 \%$ & $15.3 \%$ \\
\hline Total & 98 & 91 & 189 \\
& $51.9 \%$ & $48.1 \%$ & $100.0 \%$ \\
\hline & $X^{2}=37.514$ & DF=2 p<0.05 \\
\hline
\end{tabular}

Table 3 shows the distribution of HPVB19 IgM

Abs according to major ABO blood groups of the study population. The highest seropositivity was noticed among those with $\mathrm{O}+$ blood group while the lowest among A- \&O-ve and the difference was statistically significant $<0.05$

Table 3- The distribution of HPB19 IgM according to ABO blood groups

\begin{tabular}{|c|c|c|c|}
\hline \multirow{2}{*}{$\begin{array}{l}\text { Blood } \\
\text { groups }\end{array}$} & \multicolumn{2}{|c|}{ HPVB19 IgM } & \multirow{2}{*}{$\begin{array}{l}\text { Total } \\
\text { No. } \%\end{array}$} \\
\hline & \begin{tabular}{c}
\multicolumn{2}{c}{ Positive } \\
no. $\%$
\end{tabular} & $\begin{array}{l}\text { Negative } \\
\text { No. } \%\end{array}$ & \\
\hline $\mathbf{A B}+$ & $\begin{array}{c}9 \\
9.9 \%\end{array}$ & $\begin{array}{c}16 \\
16.3 \% \\
\end{array}$ & $\begin{array}{c}25 \\
13.2 \% \\
\end{array}$ \\
\hline A- & $\begin{array}{c}0 \\
0 \%\end{array}$ & $\begin{array}{c}7 \\
7.1 \%\end{array}$ & $\begin{array}{c}7 \\
3.7 \%\end{array}$ \\
\hline $\mathbf{B}+$ & $\begin{array}{c}25 \\
27.5 \% \\
\end{array}$ & $\begin{array}{c}23 \\
23.5 \%\end{array}$ & $\begin{array}{c}48 \\
25.4 \%\end{array}$ \\
\hline $\mathbf{O +}$ & $\begin{array}{c}\mathbf{5 0} \\
\mathbf{5 4 . 9 \%}\end{array}$ & $\begin{array}{c}23 \\
23.5 \%\end{array}$ & $\begin{array}{c}73 \\
38.6 \%\end{array}$ \\
\hline$A+$ & $\begin{array}{c}7 \\
7.7 \%\end{array}$ & $\begin{array}{c}22 \\
22.4 \%\end{array}$ & $\begin{array}{c}29 \\
15.3 \%\end{array}$ \\
\hline O- & $\begin{array}{c}0 \\
0 \%\end{array}$ & $\begin{array}{c}7 \\
7.1 \%\end{array}$ & $\begin{array}{c}7 \\
3.7 \%\end{array}$ \\
\hline Total & $\begin{array}{c}91 \\
100 \% \\
\end{array}$ & $\begin{array}{c}98 \\
100 \%\end{array}$ & $\begin{array}{c}189 \\
100 \%\end{array}$ \\
\hline
\end{tabular}

Analysis of data had been done to show the relation and distribution of HPVB19 $\operatorname{IgM}$ with the occupation of the blood donors (table4). The highest seropositive group was 
among the taxi driver (39.8\%) and the lowest

statistically significance.

was among the students this difference was

Table 4- The distribution of HPVB19 IgM with the occupation of the donors

\begin{tabular}{|c|c|c|c|}
\hline $\begin{array}{c}\text { Occupation of the } \\
\text { study }\end{array}$ & \multicolumn{2}{|c|}{ HPVB19 IgM } & Total \\
\hline population & $\begin{array}{c}\text { Positive } \\
\text { No. \% }\end{array}$ & $\begin{array}{l}\text { Negative } \\
\text { No. \% }\end{array}$ & \\
\hline Taxi driver & 39 & 4 & 43 \\
& $39.8 \%$ & $4.4 \%$ & 22.8 \\
\hline Free worker & 32 & 41 & 73 \\
& $32.7 \%$ & $45.1 \%$ & $38.6 \%$ \\
\hline Employer & 18 & 46 & 64 \\
& $18.4 \%$ & $50.5 \%$ & $33.9 \%$ \\
\hline student & 9 & 0 & 9 \\
& 9.2 & $0 \%$ & $4.8 \%$ \\
\hline Total & 98 & 91 & 189 \\
& $100 \%$ & $100 \%$ & $100 \%$ \\
\hline & & & \\
\hline
\end{tabular}

$\mathrm{X}^{2}=50.568 \quad \mathrm{df}=4 \quad \mathrm{p}<0.05$

Discussion: In this study, we found that highest

Because of its limited and restricted host

range and tropism toward immature red blood cells in the bone marrow which are the main site of its replication, HPB19 has distinctive complications in both adult and children

(Smith-Whitley K et al., 2004).

HPVB19 has strong affinity toward -P

antigen (which is a globoside: a type of glycoprotein on the surface of red blood cells, and the blood group -P phenotype determines accordingly). $\mathrm{P}$ antigen considered as receptor utilized by the virus for attachment and establishment of replication and infection level of HPV IgM was found among age group above 30 years $(\mathbf{6 2 . 6 \%})$ and the lowest level among those above 40(0\%) .The overall prevalence of IgM $51.1 \%$ this high percentage may related to the time of sampling which coincide with the maximum period of infectivity which was more common in late winter, spring, and early summer. This in agreement with other study like in Saudi Arabia which was $76.3 \%$ seropositivity (Johargy AK, 2009). These blood donors with positive IgM consider contagious because plasma and blood derivatives harbouring squat levels of parvovirus B19 look not infectious, but newly process. infected, donors may transmit the virus 
Regarding the association between ABO

blood groups and susceptibility to infection: the rate of infections was more among those with blood group $\mathrm{O}+$ and $\mathrm{B}+(54.9 \%)$ and $(27.5 \%)$ respectively, this is depending on the availability of blood antigen $\mathrm{P}$ which act as receptors for this virus. $\mathrm{P}$ antigen is very similar to blood group $\mathrm{O}$ and that's might explain the high infections among group $\mathrm{O}+$ individuals. Lastly the researcher found that the taxi drivers had the highest sropositive group $(39.8 \%)$ this is due to due being in contact with a wide variety of people from different age groups and different level of education, this in agreement of other study which found that school teachers women had highest level of infection $(16 \%, 10 / 64)$, and lowest were at homemakers $(9 \%, 4 / 46)($ Jensen IPetal.,2000).

\section{Conclusion:}

Screening for B19 virus antibodies is recommended together with other viruses which transmitted by blood transfusion to avoid transmission of this important virus to vulnerable risky group. Larger studies and researches are needed to make possible an informed decision and more sensitive and advance molecular diagnostic methods can be applied for the screening of fresh blood and its products in order to prevent the cycle of transfusion transmitted infection. 


\section{References}

1. Bärbel Kaufmann, Alan A. Simpson, and Michael G. Rossmann. The structure of human parvovirus B19. Proc Natl Acad Sci U S A. 2004 Aug 10; 101(32): 11628-11633.

2. Blaeser F., Kelly M., Siegrist K. Critical function of the CD40 pathway in parvovirus B19 infection revealed by a hypomorphic CD40 ligand mutation. ClinImmunol. 2005; 117:231237. [PubMed]

3. Cassinotti P., Siegl G. Quantitative evidence for persistence of human parvovirus B19 DNA in an immunocompetent individual. Eur J ClinMicrobiol Infect Dis. 2000; 19:886-887. [PubMed]

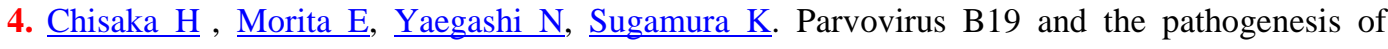
anaemia. Rev Med Virol. 2003 Nov-Dec; 13(6):347-59

5. H. L. Zaaijer, Koppelman and C. P. Farrington. Parvovirus B19 Viraemia in Dutch Blood Donors. Epidemiology and Infection. Vol. 132, No. 6 (Dec., 2004), pp. 1161-1166.

6. Jensen IP, Thorsen P, Jeune B, Møller BR, Vestergaard BF. An epidemic of parvovirus B19 in a population of 3,596 pregnant women: a study of sociodemographic and medical risk factors. BJOG. 2000 May; 107(5):637-43

7. Johargy AK.seroprevalence of erythrovirus B19 IgG among Saudi blood donors in Makkah,Saudi Arabia . J Family Community Med. 2009 Sep; 16(3):111-4.

8. Ke L, He M, Li C, Liu Y, Gao L, Yao F, Li J, Bi X, Lv Y, Wang J, Hirsch ML, Li W. The prevalence of human parvovirus B19 DNA and antibodies in blood donors from four Chinese blood centers. Transfusion. 2011 Sep;51(9):1909-18. doi: 10.1111/j.1537-2995.2011.03067. x. Epub 2011 Mar 7.

9. Manaresi E, Gallinella G. Seroprevalence of parvovirus BI9 among Italians blood donors. Epidemi. of infect. 2004; 132 (5):857-862.

10. Musa, Sunday A. U Prof. B anwat, E dmund B Zhakom Ponfa; Rumji, E lisha M Yakubu, Rebecca; Yakubu, R ebecca K. and Rufai, O lalekan A. Risk of Transfusion-Transmitted Human Parvovirus B19 Infection in Anyigba and Lokoja, Kogi State. Iosr Journal of Pharmacy Volume 3, Issue 3 (April 2013), Pp 66-70.

11. Satish Kumar $, \underline{\text { R.M. Gupta, }} \underline{\text { Sourav Sen}}, \underline{\text { R.S. Sarkar, }} \underline{\text { J. Philip, }}$ Atul Kotwal,and $\underline{\text { S.H. }}$.

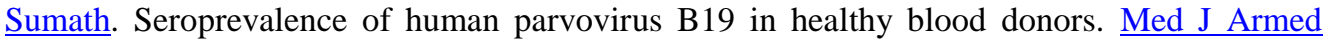
Forces India. 2013 Jul; 69(3): 268-272.

12. Smith-Whitley K, Zhao H, Hodinka RL, Kwiatkowski J, Cecil R, Cecil T, Cnaan A, OheneFrempong K. Epidemiology of human parvovirus B19 in children with sickle cell disease. Blood. 2004 Jan 15;103(2):422-7. Epub 2003 Oct 2.

13. Wei $\mathrm{O}$, Li Y. prevalence of anti human parvovirus anti-body among blood donors in Jilin province China. 2006 Jun; 20(2): 60-2. 


\section{utjmed@utq.edu.iq}

14. Yoto, Y., Kudoh, T., Haseyama, K., Suzuki, N., Oda, T., Katoh, T. and Chiba, S. Incidence of Human Parvovirus B19 DNA Detection in Blood Donors. British Journal of Haematology (2008). 91 (4): 1017 - 1018. Available at www3.interscience.wiley.com/journa

15. Young NS, Brown KE."Parvovirus B19". N Engl J Med. (February 2004). 350 (6):586597.Doi :10.1056/NEJMra030840. PMID 14762186

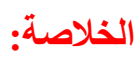

تعتبر عملية نقل الدم ومنتجاته واحده من اهم الطرق لانتقال فايروس البارفو ب 9 1. على الرغم من ارتباط هذا الفيروس مع بعض المضاعفات الثديدة الا انه لا يوجد فحص اختباري مستمر للكثنف عنه ولذلك كان الهدف

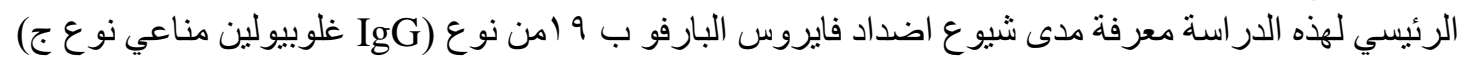

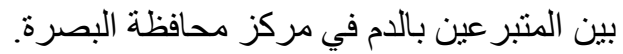
تم جمع و1 ا عينة دم من الاشخاص الاصحاء المنبرعين بالدم، وتم قياس مستوى الاضداد في عينات الدم بو اسطة طريقة المقايسة المناعية المرتبطة بالأنزيم (الاليزا).

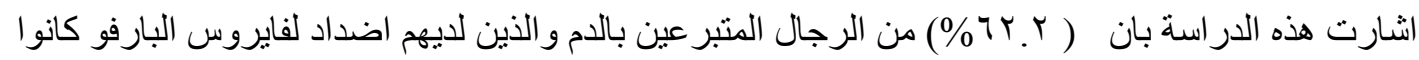

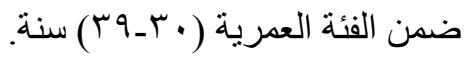

اما بالنسبة لمدى علاقة الخمج الفايروسي مع نوع فصيلة الدم، وجدنا بانه اعلى نسبة للمستضدات كانت لدى

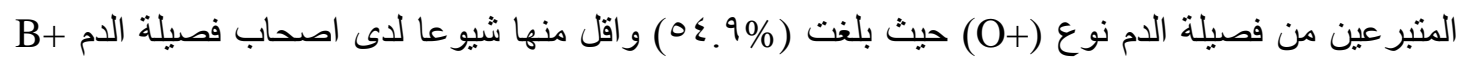

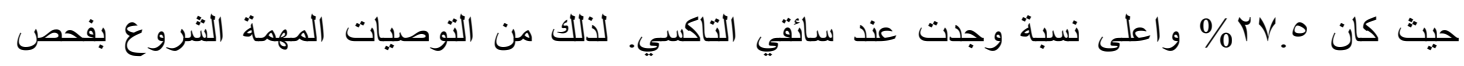
مضادات فايروس بارفو بـ9 1 منز امنا مع الفحوص المختبرية الاخرى للمتبر عين بالدم. 